\title{
On the Himalayan Uplift and Himalayan Corridors
}

\author{
Hideo Tabata \\ Gifu Academy of Forest Science and Culture, Mino 501-3714, JAPAN
}

For correspondence, E-mail: tabata@forest.ac.jp

It isnecessaryto review studiescarried outin theHimalayas from the interdisciplinary viewpoints for a comprehensive understanding of somefeatures of Himalayan vegetation and the patterns of distribution of someplants, especially in connection with theHimalayan orogeny.

\section{Himalayan corridors}

Kitamura (1955) postulated that the temperate zone of the southern side of the Great Himalayas represented a corridor through which Sino-Japanese plants migrated westwards, and named it theHimalayan corridor. However, hedid not pay much attention to theeastward distribution of Mediterranean elements through the corridor and extended theSino-Japanese region up to Afghanistan by drawing the Himalayan corridor (Kitamura, 1957).

The southern slopes in the Himalayas are generally drier than the northern slopes. In the case of the Great Himalayas, however, thesouth-facing slopeis moister than the north facing one. Therefore, therearetwo corridorsalong the Outer and Lesser Himalayas respectively, on the south facing slopes and on the north facing slopes, and the Great Himalayas provide a corridor on its southern slope. The northern side of the Great Himalayas can not act as a corridor due to its dryness.

The eastern elements extended their distribution range westwards through the moister corridor and the western elements migrated eastwards through the drier corridor. However, for example, wet sal (Shorea robusta) forest occurring on the south-facing slopes of the Siwalik range in Central Nepal can not surviveon thesouth facingslopes in thewestern Siwaliks. It moves to the north-facing slope and it is replaced by the dry hill sal forest in the west Si walik range. Thedry hill sal forest gives place to the subtropical decidous hill forest dominated by Anogeissuslatifolia in thewest Siwalik. The deciduoushill forest dominated by Anogeissuslatifolia is replaced by the subtropical scrub composed of Olea cuspi data, Dodonea viscosa etc. in the further west. On thenorth-facingslope, thewet Sal forestreplaces Castanopsisindica- Schima wallichiana forest in the west Siwalik where the dryness caused by the increase of mediterraneity of climateis prevailing. TheSiwalik range provides corridors on the south and north sides of the range for theeastward migration of western elements and westward distribution of eastern elements. In the Lesser Himalayas, Quercuslanuginosa-Q. incana forest is replaced by Q. incana forest in West Nepal, and Q. incana forest occurs on theall exposures in West Nepal and Kumaon region in India and then it is confined to the northern side of the Lesser Himalayas westwards. Cedrus deodara forest replaces Q. incana forest on the southern slopes of the western Lesser Himalayas whereQ. incana forest moveto thenorthern side. TheHimalayan corridors are twisted in this way.

Historical sketch of Himalayan corridors

Prakash (1978) and Awasthi (1982) reported that the tropical forests covered the Siwalik area before its uplift in the lower Miocene. Thefirst record of the Mediterranean elements in the
Himalayan area was found above the sterile deposits indicating theuplifting of themain Himalayan ridgein themiddleM iocene. This suggests that a simple Himalayan corridor was formed on the southern side of the main range in the upper Miocene. The prototype of Himalayan corridors was formed by the uplift of Outer and Lesser Himalayas.

Guo et al (1976) reported that the macrofossils and pollen of many temperate tree species (Betula, Alnus, Carpinus, Magnolia, Cedrus, Abies, Picea, Sabina, Lespedeza etc.) werefound from the deposits of the last Interglacial period (Kangbula Interglacial). They concluded that the Great Himalayas experienced abruptand a large-scaleuplift during thelast Glacial period.

Stainton $(1972,1977)$ recognized that there are two kinds of distributional gaps of Himalayan plants: oneis theEastNepalSikkim Gap and theother istheSino-West Himalaya Gap. Actaea spicata, Lonicera quinquelocularis, L. webbiana, Plectranthus rugosus, Ribes al pestre, R. emodense, Sorbaria tomentosa, Viburnum cotinifolium etc. show the former type of distribution gap. Although Stainton reasonably discussed about discontinuity in the distribution of the former by the specialty of wet climate and the lack of themedium-dry habitatsin EastNepal and Sikkim, and the reoccurrence of drier conditionsin Bhutan, hecould not elucidatethelatter discontinuity. Acer caesium, Cotinuscoggygria, Olea ferruginea, Quercus dilatata, Incarvillea arguta, Clematis grata etc. have the latter discontinuity pattern.

I havediscussed this big distribution gap in connection with the Himalayan uplift (Tabata, 1988, 1998). Chinese scientists showed that many temperate trees including Cedrus, one of western elements, occurred on the northern side of the Great Himalayas in the last Interglacial. It means the presence of the Himalayan corridor through which the western elements, preferring drier conditions, migrated eastwards up to the southwestern part of China during the last Interglacial period. The corridor on the northern side disappeared after the abrupt and drastic uplift during the last Glacial period and the big discontinuity of distribution range of plants, which were separated in West Himalayas and Southwest China, was formed by this kind of event in the Great Himalayan area during the last Glacial period.

There is another evidence to show the existence of the Himalayan corridor on thenorthern side of the Great Himalayas. The palynological study (Yoshida et al., 1984) showed that Abies, Picea, Larix, Tsuga and Pinuswere found together with Quercus, Keteleeria, Myrica, Podocarpus, Sapium etc. from the Tetang Formation in Thakkhola (the upper stream area of the present Kaligandaki river). It is especiallyimportant that theoccurrence of Keteleria was confirmed from theTetang Formation. Keteleria is a warm temperate, sometimes subtropical, conifer which isnow confined to the southern China though it was distributed from Asia to Europein the Miocene. This suggests that theHimalayan corridor on the northern side of the Great Himalayas existed in thelower Neogene. TheAnnapurna-Dhaulagiri mountains were high enough for the growth of Picea and Abies, and the altitude of 
the mountains is estimated to be between $3500 \mathrm{~m}$ and alittlebit higher than $4000 \mathrm{~m}$ asl. It is estimated from the presence of temperate and cold temperate trees that the AnnapurnaDhaulagiri mountains were not so high as to block themonsoon and the moist air reached up to Thakkhola area where the dry climate is prevailing and no forests are available now.

\section{References}

Awasthi N. 1982. Tertiary plant megafossils from the Himalaya-a review. The Palaeobot 30: 254-267.

Guo X. 1976. Quaternary Interglacial Period and Palaeoclimate in the Zhumulangma Region. In: Zhumulangma Region Scientific Report. Beijing: Science Publishers. p 63-78

Kitamura S. 1955. Flowering plants and ferns. In: Kihara H (ed), Fauna and flora of Nepal Himalaya. Kyoto: Fauna and Flora Research Society. p 73-290

Kitamura S. 1957. Colored Illustrations of Herbacious plants of Japan I. Osaka: Hoikusha Pub. (in Japanese)

Prakash U. 1978. Some more fossil woods from the Lower Siwalik beds of Himachal Pradesh, India. Him Geol 8: 61-81.

Stainton JDA. 1972. Forest of Nepal. London: John Murray.

Stainton JDA. 1977. Some problems of Himalayan plant distribution. Colloques internationaux du C.N.R.S. 268: 99-102

Tabata H. 1988. On the Himalayan corridor. Acta Phytotax Geobot 39: 1324 (in Japanese with English summary)

Tabata H. 1998. Himalayan Uplift, Plant Corridors and the Past Climate. Himalayan Geol 19(2):61-63

Yoshida M, Igarashi Y, Arita K, Hayashi D and Sharma T. 1984 Magnetostratigraphic and pollen analytic studies of theTakmar series, Nepal Himalayas. J Nepal Geol Sci 4: 101-120 